fered no hope for empowerment. By optimistic contrast, one of my former students, E. Joyce Parker, suggested that all students can use for their own purposes the core concepts and texts of even an unreconstructed political science. It was a very vigorous discussion.

Since not every member of the APSA could be present, it seemed worthwhile to generate some permanent record. What follows is a somewhat shortened version of the session, edited down in consulta- tion with each speaker. The essays are printed in their order of appearance in the panel session; panelists' suggestions for material to use in mainstreaming are included.

As facilitator for this composite piece as well as the panel session, I thank all the participants again. The opinions, as presented, are those of the individual authors. We hope that our perspectives will interest and, above all, help our colleagues.

\title{
Incorporating A Women's Studies Dimension Into Mainstream Political Science Courses
}

\author{
Martin Gruberg, University of Wisconsin, Oshkosh
}

In more than 30 years of teaching, I have taught a multitude of courses. Almost from the start, I was able to use women's studies material in my classes. Some courses were by their nature heavily dependent on a women's dimension (Women and the Law, seminar on Women's Liberation, field trip classes on the European Women's Rights Movement) while others, like Police-Community Relations, had possibilities that I exploited.

More important are the limited number of courses I teach on a regular basis. For example, my course on the Legal Rights of the Disadvantaged deals with the civil rights of women and other groups, incorporating topics that had been part of the Women and the Law course (which I discontinued offering because of an anemic enrollment). In it, I look at a spectrum of organizations that provide help for the underdog, as well as the constitutional framework and areas of equity concern (education, employment, reproductive freedom, domestic relations, public accommodations, governmental services, criminal justice), treatment in the media.

For mainstream courses, I use a number of topics to blend in a women's studies component. For
American Government, this means mainly the sections on the Constitution but also those on civil liberties and civil rights as well as on interest groups and political parties. For Introduction to Law, I found that material on women fits well into the sections on the history of law, on private legal systems, on "Big Brother and the Law," and also on philosophies of law and legal reasoning. In my course on Civil Liberties, I deal with women's rights as human rights under the section about the justifications for civil liberties; under freedom of expression I include impact on women; and under defendants' rights I discuss crimes against women and women in the criminal justice system. Finally, in a course on American Political Parties, I discuss women in the sections on the political process as a whole, interest groups, parties and elections, and voting behavior (including the gender gap).

A number of years ago I undertook to be a resource person for my departmental colleagues regarding recent literature and audiovisual aids on women and politics. From time to time I prepared annotated listings of items that they might be able to use in their courses. I also volunteered to be a guest lecturer in their courses. The response was

\section{Reference}

Gates, Henry Louis, Jr. 1993. “Backlash?” New Yorker, May 17, 42-44.

\section{About the Author \\ Naomi Black is professor of political science at York University, Toronto, Canada.}

underwhelming, so I thought there would be some interest in finding out what, if anything, my political science colleagues at Oshkosh now do with respect to integrating a women's studies dimension into their courses.

I sent a short questionnaire to the other department members, all male, and received the following responses. One colleague mentioned that in his Introduction to Politics he discussed the population problem and women in the Third World. Another included in his course on American government some discussion of gender issues including abortion as well as (women's) civil rights, women's interest groups, and gender behavior. A public administration course included some consideration of affirmative action, comparable worth, and pay equity issues in the public sector. State and Local Government looked at civil rights and female participation in decision making in legislative bodies; Congress in the American Political System looked at the Black caucus and gender representation in Congress; and Modern Political Thought had the students read and discuss Mill's The Subjection of Women

Courses taught by my colleagues in which they did not integrate a women's studies dimension in- 
cluded The Politics of Oil, Middle East Government and Politics, U.S. Foreign Policy, War and Peace, and Latin American Government and Politics. Certainly it would be possible to incorporate a women's studies dimension into those courses. My male colleagues may have had a blind spot in that regard-or maybe they thought the subject insignificant!

\section{References}

American Political Science Association. Module booklets in the APSA's Citizenship and Change: Women in American Politics (1988) (such as M.L. Shanley, Women's Rights, Feminism, and Politics in the United States). Washington: APSA

Gruberg, Martin M. 1968. Women in American Politics: An Assessment and Source Book. Oshkosh, WI: Academia.

\title{
Organizing A Course That Is Attentive to Issues of Racial and Sexual Difference
}

\author{
Helene Silverberg, University of California, Santa Barbara
}

"M ainstreaming" race and gender is the next intellectual frontier in building a curriculum that is enriching to us all. Of course, mainstreaming implicates many large issues of pedagogy - from the nature and uses of liberal education to the proper relationship between the classroom and the social context in which we teach and learn. But I shall confine my remarks here to some observations about the practical task of organizing a course that is attentive to issues of race and gender.

In my view, the conventional approach to mainstreaming - which could be described as "add women and/or Blacks and stir"'-raises more problems than it solves. My own early efforts to construct an inclusive syllabus ran into some troubling problems. I found, for example, that only the African American students read the assigned material about African Americans and only the women students read the assigned material about women. The White male students read only the material that did not include the words "race" and "sex" in the title. In effect, the "add and stir"' approach had the unfortunate effect of polarizing class discussion rather than educating everyone.

Moreover, the "add and stir" approach sends several wrong messages. It implies that studying race and gender means examining the political behavior and experience of women and African Americans. But by studying only subordinate groups, we obscure the ways in which dominant groups (i.e., Whites and men) are implicated in the unequal social relations of race and gender. It also assumes that issues of race and gender are present in politics only if women and/or African Americans are physically present in any given instance. This approach limits the topics into which race and gender can be sensibly integrated.

Most importantly, the "add and stir" approach conflates the key distinction between race and sex as biological characteristics (which, of course, they are) and race and gender as political categories, cultural constructions, and markers of inequality (which they need not be). This approach reflects the positivism and methodological individualism of much work in our discipline. And it has greatly misled us about the appropriate object of our study of race and gender.

I use two different approaches in organizing my syllabus and, perhaps more importantly, in teaching the material on the syllabus. First, I often employ gender as a theoretical lens in my discussion of different topics on my syllabus. During the discussion of the welfare state, for example, I challenge the conventional view that welfare states developed at the contested inter- section of (gender- and/or race-) neutral capitalism, democracy, and citizenship, and that they were built by labor unions, policy experts, state bureaucrats, and political elites. Drawing on recent research that uses gender as its analytical lens, I demonstrate that the conventional view is a partial view, that men and women following different policy agendas and political strategies built the welfare state, and that the appropriate relations between the sexes was as much at stake as the relations between the classes.

At other times, I focus on race and gender as collective identities and sources of social solidarity (rather than attributes of individuals) that are created in/through political processes and political institutions. During my discussion of political parties or policy making, for example, I challenge the notion that race and gender are static and unchanging political categories. Using recent work on the Great Society, I show how the racial targeting of many policies politicized racial identities among both Blacks and Whites. I also show how the new politicization of identities helped to reorganize American politics by fragmenting the Democratic party's biracial coalition and opening the way for a newly invigorated allWhite, cross-class Republican party.

These two approaches have several advantages. They emphasize 